\title{
Are Women in BOD Affecting the Company's Financial Performance?
}

\author{
Darren, Sumani* \\ Atma Jaya Catholic University of Indonesia \\ Jakarta, Indonesia \\ *sumani@atmajaya.ac.id
}

\begin{abstract}
This research aims to provide advice to policy makers to increase the number of women on the board of directors with the aim of improving company performance. The purpose of this study is to look at the effect of women in the board of directors on company performance. Previous studies that have been conducted regarding the effect of women's representation in the board of directors on financial performance shows the inconsistency of research results. then the writer wants to want to re-examine the important role of women in the board of directors. This research was conducted on 47 manufacturing companies listed on the Indonesia Stock Exchange in the 20142018 period. This study uses random effect model for regression analysis. The results of the regression analysis show that the women in the board of directors had a significant positive effect on company performance.
\end{abstract}

Keywords-board of directors, company performance, female directors, financial performance

\section{INTRODUCTION}

Every public company has a board of directors whose job is to control the company's performance and determine the company's strategy. The performance of a company can be seen from the company's financial performance, where a good corporate financial performance will attract investors. Based on CWDI [1], the average representation of women in the board of directors of Indonesian companies is $11 \%$, below Malaysia $(11.7 \%)$ and Vietnam (13.9\%) in the Southeast Asian region. The average representation of women in the ranks of directors of Indonesian companies is still relatively small compared to the United States (19.2\%), Canada (20.8\%), Italy (22\%), and France $(32.3 \%)$. The underrepresentation of women in the ranks of directors of Indonesian companies is partly due to cultural factors, where the community considers that women have no leadership ability compared to men.

Research conducted by Pletzer et al. [2] of 3097 companies throughout the country from 20 journals from EBSCO shows that women's representation in the board of directors has insignificant and positive influence on company performance. Research conducted by Martinez et al. [3] on non-financial companies on the Madrid Stock Exchange in 2004-2013 shows that the representation of women in the board of directors has a significant and positive influence on company performance. Kilic and Kuzey [4] study of 149 Turkish non-financial companies listed on the Istanbul Borsa Stock Exchange in the 2008-2012 period showed that gender diversity within the board of directors had a significant and positive influence on company performance. Research conducted by Routray and $\mathrm{Bal}$ [5] on the 162 largest companies listed on the Indian Stock Exchange in 2016 showed that the composition of the board of directors had an insignificant and positive influence on company performance. Then, research conducted by Abdelzaher [6] of 114 non-financial companies listed on the Egyptian Stock Exchange in 2013 showed that the representation of women in the board of directors had a significant and positive influence on company performance.

Judging from previous studies that have been conducted on the effect of women's representation in the board of directors on financial performance shows the inconsistency of the results of the study so that the authors feel the need to re-do research on the effect of women's representation in the board of directors on the financial performance in companies listed on the Indonesia Stock Exchange for the period 2014-2018.

\section{LITERATURE REVIEW}

Performance is a form of achieving the company's success in managing its activities [7]. One way that can be done to measure a company's financial performance is to use Tobin's Q ratio. Companies with high $\mathrm{q}$ ratios tend to have attractive investment opportunities or significant competitive advantages (or both) [8] Regarding to corporate performance, LückerathRovers [9] said that higher return on equity is consistently and statistically significantly for companies with women on the board than for companies without women on the board. In addition, Isidro and Sobral [10] said that female directors contribute in giving thought and motivating the board of directors to learn about other solutions regarding the problems facing the company. Regarding the supply of products to consumers, Triana et al. [11] and Liu et al. [12] say that female directors can encourage a better understanding of consumer demand and needs in the market in order to achieve business stability and corporate sustainability. 
Rossi et al. states that corporate governance is a system of principles, regulations, and provisions that cover the management, practices, and structure of corporate ownership. Corporate governance is the main factor that determines the company's financial growth and the level of investor confidence in the company [13]. Dharmastuti et al. said that the balance and effectiveness of corporate governance mechanisms can create better financial performance [14]. Fauzi et al. states that gender diversity within the board of directors has been a topic of discussion in corporate governance, especially in the past 10 years. Regarding corporate governance [15], Alvarado et al. said that the representation of women in the board of directors is a good indicator of corporate social responsibility and a sign that the strategy chosen by the company is a stakeholder-oriented strategy [16]. An entity with gender diversity in its board of directors gives a positive signal to the public related to ethical actions taken by the company [17]. So the public will assume that the company has done good governance, and the company gets the trust of the public (consumers or potential customers).

Caselli states that the separation between principals and agents in a company will produce asymmetric information and incomplete contracts between the two parties, this is what cause agency problems in a company, even though the principal has delegated the agent to act in their interests [18]. Martinez et al. [3] states that board composition is a key mechanism for reducing or eliminating agency costs in the company and aligning the interests of principals and agents, focusing on control as the most important function of the board of directors. One mechanism that can be done to minimize agency costs and realize good corporate governance is to present women in the board of directors as one of the company's management decision makers. Cardillo et al. [19] states that gender diversity is also positively related to bank performance, as proxied by ROA and Tobin's Q and with dividend payout ratios, consistent with the hypothesis that female directors are better monitors than male directors. Based on these previous researches, the hyphothesis in this research is women in the board of directors has a positive influence on company performance.

\section{METHODS}

The data in this study were sourced from www.idx.co.id, the website of each company, and finance.yahoo.com. The population of this study is all manufacturing companies listed on the Indonesia Stock Exchange in the 2014-2018 period. The sample selection uses the following criteria: Manufacturing companies listed on the Indonesia Stock Exchange for the period 2014-2018; The company must publish the financial statements that have been audited by independent public auditors for the 2014-2018 period; The company's financial statements are presented in rupiah; The selected companies are 3 companies that have the greatest asset value from each subsector.

Regression analysis in this study is a simple regression analysis, with the following research models:
$\mathrm{Y}=\beta 0+\beta 1 \mathrm{FBOD}+$ eit.

Where:

$\mathrm{Y}=$ company performance measured by Tobin's $\mathrm{Q}$

$\beta 0=$ intercept coefficient

$\beta 1=$ regression coefficient

FBOD $=$ representation of women in the board of directors as measured by a dummy variable.

$\varepsilon i t=$ error term

The independent variable in this study is the representation of women in the board of directors. This variable is measured using a dummy variable. A dummy variable is 1 if the sample has 1 or more female directors in its board of directors, a dummy variable will be 0 if the sample does not have a female director in its board of directors.

Company performance is measured by Tobin's Q. Tobin's Q is a ratio to measure company performance, specifically about the company's value, which shows a professional management in managing company assets. The reason researchers use Tobin's Q to measure company performance is because Tobin's $\mathrm{Q}$ reflects market expectations so that it is relatively free of possible manipulation by company management. This variable is measured by a ratio scale. Tobin's Q is formulated as follows Aftab et al. [20].

$$
\text { Tobin's } Q \text { Ratio }=\frac{M V S+D}{T A}
$$

Where:

MVS = market value of all outstanding shares

$\mathrm{D}=$ debt

$\mathrm{TA}=$ total assets

\section{RESULTS AND DISCUSSION}

\section{A. Results}

The random effect model was chosen as the regression analysis model after conducting a Chow test and a Hausman test. Regression analysis uses a significance level of $5 \%$.

Following are the regression results from the hyphothesis:

TABLE I. RESULTS OF REGRESSION ANALYSIS

\begin{tabular}{|l|l|l|l|c|}
\hline Variable & Coefficient & Std. Error & t-Statistic & Prob. \\
\hline C & 1.482257 & 0.424221 & 3.494067 & 0.0006 \\
\hline FBOD & 1.020077 & 0.269746 & 3.781627 & $0.0002 * *$ \\
\hline \multicolumn{5}{|c|}{$* *$ mean that the p-value < $<\%$} \\
\hline
\end{tabular}

Based on the results of the regression analysis above, it can be said that the hypothesis namely the representation of women in the board of directors has a positive influence on company performance proven because the $\mathrm{p}$-value $<\alpha(0,0002<0.05)$. 


\section{B. Discussion}

The results of the regression analysis showed that the representation of women in the board of directors had a significant and positive influence on company performance. These results are in line with conceptual hypotheses and research conducted by Martinez et al. [3], Kilic and Kuzey [4] and Abdelzaher [6]. Agency theory states that the representation of women in the board of directors can strengthen the control mechanism of managers in the company [16], this is because gender diversity in the board of directors increases independence in the board of directors, women strengthen the control function at the board of directors because generally women are more conscientious and question managers more than men, so monitoring costs incurred by principals (shareholders and other stakeholders who use company financial information) can be minimized. By minimizing this agency problem, the company can be said to have done good corporate governance. Companies that conduct good governance will get the trust of investors. The trust of investors will lead to an increase in stock prices so that investors get the expected return from a stable capital gain so that it can be said the company has a good performance.

In addition, Lückerath-Rovers [9] said that on average the presence of women on the board is a distinctive feature of companies that perform better. In addition, signaling theory says that the representation of women in the board of directors signifies a positive signal sent by the company to the public, especially potential investors. Fernandez-Feijoo et al. [21] said that the representation of women in the board of directors could convey a transparent image of the board of directors. Then, Triana et al. [11] said that racial and gender diversity has a relationship with company performance, the relationship between racial and gender diversity and company performance operates through corporate reputation and innovation as a mediator. This positive signal will be considered by investors to buy shares of the company which will have an impact on increasing share prices so that the company's performance is said to improve.

\section{CONCLUSIONS}

Based on the results of the study, it can be concluded that the representation of women in the board of directors has a significant and positive influence on company performance. Based on the conclusions obtained from the results of the study, the researcher wants to convey a number of suggestions, namely: for the company, it should appoint women to fill roles in its board of directors because it can improve company performance so that it can attract investors. For investors, especially long-term investors, this research can be used as a material consideration in choosing the company to be invested. Consideration for investors to invest in companies that have women in their board of directors because it is proven by the representation of women in the company's board of directors that can improve company performance so that it will be more profitable for investors.

\section{REFERENCES}

[1] 2015 CWDI Report On Women Board Directors of APEC Economies Key Findings. Washington, DC, 2015.

[2] J. Pletzer, R. Nikolova and K.K. Kedzior, "Voelpel SC. Does gender matter? female representation on corporate boards and firm financial performance - A meta-analysis," PLoS ONE, Vol. 10, No. 6, 2015

[3] M.C.P. Martinez, I.B. Oms and G.O. Sempere, "Female institutional directors on boards and firm value," Journal of Business Ethics, Vol. 152, pp. 343-63, 2016.

[4] M. Kilic and C. Kuzey, "The effect of board gender diversity on firm performance: evidence from Turkey," Gender in Management, Vol. 31, No. 7, pp. 434-55, 2016.

[5] S.K. Routray and R.K. Bal, "Board composition, board diversity and firm performance: evidence from India," Asian Journal of Business Ethics, Vol. 5, No. 1-2, pp. 1-18, 2016.

[6] A. Abdelzaher and D. Abdelzaher, "Women on board and firm performance in egypt: post arab spring," The Journal of Developing Areas, Vol. 53, No. 1, pp. 225-41, 2019.

[7] N.A. Walidayni, Pengukuran kinerja keuangan dengan menggunakan Tobins Q. E-Jurnal UIN Sunan Kalijaga Yogyakarta, 2016.

[8] S.A Ross, R.W. Westerfield, B.D. Jordan, J. Lim and R. Tan, Fundamentals of Corporate Finance. 2nd ed. New York: McGraw-Hill Education, 2016.

[9] M. Lückerath-Rovers, "Women on boards and firm performance," Journal of Management \& Governance, Vol. 17, pp. 491-509, 2013.

[10] H. Isidro and M. Sobral, "The effects of women on corporate boards on firm value, financial performance, and ethical and social compliance," Journal of Business Ethics, Vol. 132, No. 1, pp. 1-19, 2015.

[11] M. Triana, T. Miller and Trzebiatowski, "The double-edged nature of board gender diversity: Diversity, firm performance, and the power of women directors as predictors of strategic change," Organization Science, Vol. 25, pp. 609-32, 2014.

[12] Y. Liu, Z. Wei and F. Xie, "Do women directors improve firm performance in China?," Journal of Corporate Finance, Vol. 28, 2014

[13] F. Rossi, R.J. Cebula and J.R. Barth, "Female representation in the boardroom and firm debt: empirical evidence from Italy," Journal of Economics and Finance, Vol. 42, No. 2, pp. 315-38, 2017.

[14] C. Dharmastuti and S. Wahyudi, "The effectivity of internal and external corporate governance mechanisms towards corporate perforamance," Research Journal of Finance and Accounting, Vol. 4, No. 4, 2013.

[15] F. Fauzi, A. Basyith and P.L. Ho, "Women on boardroom: does it create risk?,” Cogent Economics \& Finance, Vol. 5, No. 1, pp. 118-32, 2017.

[16] R.N. Alvarado, B.J. Laffarga and Fuentes RP De, "Gender diversity on boards of directors and business success," Investment Management and Financial Innovation, Vol. 8, No. 1, pp. 199-209, 2011.

[17] S. Terjesen, E.B. Couto and P.M. Francisco, "Does the presence of independent and female directors impact firm performance? A multicountry study of board diversity," Journal of Management \& Governance, Vol. 20, No. 3, pp. 447-83, 2015.

[18] S. Caselli and Giulia Negri, Theoretical Foundation of Private Equity and Venture Capital. Private Equity and Venture Capital in Europe (Second Edition). 2nd ed. Elsevier Science Publishing Co Inc; 2018.

[19] G. Cardillo, E. Onali and G. Torluccio, "Does gender diversity on banks' boards matter? Evidence from public bailouts," Journal of Corporate Finance, 2020.

[20] A. Ahmed, M.K. Khurshid, and M.U. Yousaf, "Impact of Intellectual Capital on Firm Value: The Moderating Role of Managerial Ownership," Preprint, 2019.

[21] B. Fernandez-Feijoo, S. Romero and S. Ruiz, "Does board gender composition affect corporate social responsibility reporting?," International Journal of Business and Social Science, Vol. 3, No. 1, pp. $31-8,2012$ 